\title{
En mann med erytrodermi, muskelsvakhet og vekttap
}

\author{
En mann med psoriasis utviklet forhøyet nivå av lever- og muskel- \\ enzymer, proksimal muskelsvakhet, erytrodermi og nedsatt allmenn- \\ tilstand. Histologisk undersøkelse av muskelbiopsi viste imidlertid \\ ingen sikre tegn på polymyositt eller dermatomyositt.
}

Se kommentar side 2242 og kunnskapsprøve på www.tidsskriftet.no/quiz

En mann i slutten av 50-årene hadde hatt psoriasis og keratosis palmoplantaris $i$ mange år. Han hadde i flere år blitt behandlet med acitretinkapsler (Neotigason 25-50 mg daglig) og det ble ved rutinekontroll påvist stigning av leverenzymer. Serumkonsentrasjonen av $\gamma G T$ steg $i$ løpet av to år fra $100 \mathrm{U} / \mathrm{l}$ (normalt 15-115 U/l) til $300 \mathrm{U} / \mathrm{l}$. Ved kontroll om høsten to år senere var $\gamma G T$ steget til $559 \mathrm{U} / \mathrm{l}$. Han utviklet i løpet av denne høsten erytrodermi og smerter i ledd.

Pasientens hudlege antok at økningen av $\gamma$ GT skyldtes acitretin, som ofte er levertoksisk (1). Behandlingen med acitretin ble derfor avsluttet. I tillegg ble det ved lokalsykehuset utført MR- og CT-undersøkelse av lever, der man fant normale forhold bortsett fra to større områder tolket som hemangiomer i høyre leverlapp. Det ble anbefalt fra lokalsykehuset at MR-undersøkelsen skulle gjentas om et år.

Etter seponeringen av acitretin økte det rødflammede utslettet både $i$ intensitet og utbredelse. Utover høsten merket pasienten også stadig feber rundt $38^{\circ} \mathrm{C}$ og han følte seg allment syk. Senere tilkom smerter $i$ flere store ledd, og kraften avtok i armer og

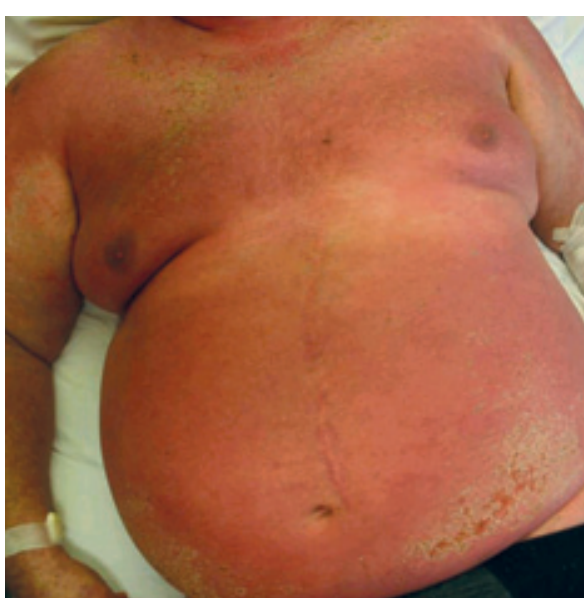

Figur 1 Erytrodermi. Generalisert erytematøst utslett bein. Han merket spesielt at det ble tyngre å gå i trapper. Pasienten ble derfor innlagt til utredning ved Hudavdelingen ved Rikshospitalet. Det kom da frem at pasienten hadde hatt et vekttap på $10 \mathrm{~kg}$ de siste to månedene. Ved innleggelsen ble det påvist periorbitalt ødem med heliotropt erytem, Gottrons papler over de fleste fingerknoker (mellomledd (PIP) og grunnledd (MCP)) og

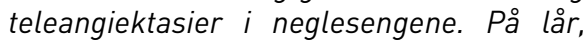
nedre del av abdomen, øvre del av rygg og $i$ halsutskjæringen fant man dermatittforandringer og enkelte erosive forandringer (fig 1). I håndflatene ble det iakttatt hyperkeratose. Blodtrykket var $96 / 78 \mathrm{~mm} \mathrm{Hg}$. Analyser av blod viste følgende: $S R 69 \mathrm{~mm} / \mathrm{t}$, CRP $32 \mathrm{mg} / \mathrm{l}$ (normalt < 4), ASAT $487 \mathrm{U} / \mathrm{l}$ (normalt 15-45), ALAT $110 \mathrm{U} / \mathrm{l}$ (normalt 10-70), LD 563 U/l (normalt 105-205), ALP $188 \mathrm{U} / \mathrm{l}$ (normalt 35-105), $\gamma$ GT $559 \mathrm{U} / \mathrm{l}$ (normalt 15-115), kreatinin $148 \mu \mathrm{mol} / \mathrm{l}$ (normalt 60-105), glomerulær filtrasjonsrate (GFR) $42 \mathrm{ml} / \mathrm{min} / 1,73 \mathrm{~m}^{2}$, serum-albumin $30 \mathrm{~g} / \mathrm{l}$ (normalt 36-45), natrium $126 \mathrm{mmol} / \mathrm{l}$ (normalt 137-145), kalsium 2,13 mmol/l (normalt 2,15-2,51), kreatinkinase (CK) $9222 \mathrm{U} / \mathrm{l}$ (normalt <270). Urinstiks viste $3+$ på protein. Protein-kreatinin-ratio i urin var $62 \mathrm{~g} /$ $\mathrm{mmol}$ (normalt < 30). Antinukleære antistoffer ble ikke påvist, heller ikke myosittspesifikke autoantistoffer lanti-Mi-2, anti-Ku, anti-Pm/Scl, anti-Jo-1, anti-PL12 og anti$P L-7)$. Hudbiopsi viste hud med fokal hyperkeratose, epidermal atrofi og lichenoid betennelse forenlig med dermatomyositt. Immunnedslag ble ikke påvist lanti-hud-IFnegativ). MR-undersøkelse av lår viste uttalte signalforandringer $i$ muskulatur og subkutant vev forenlig med ødem. Bakteriologisk undersøkelse fra hudkruste ga oppvekst av gule stafylokokker.

Klinisk forelå det en erytrodermi, og funnet av Gottrons papler, V-tegn (erytematøst utslett på fremre thorax omkring halsutringningen), teleangiektasier, heliotropt utslett, nedsatt allmenntilstand, kraftsvikt i proksimal muskulatur, svelgproblemer og forhøyede muskelenzymer tydet sterkt på dermatomyositt. Signalforandringene i muskulatur (ødem) påvist ved MR var også forenlig med betennelsesaktig muskelsykdom. Pasienten ble derfor overflyttet til revmatologisk avdeling for videre utredning og behandling. Det ble her påvist nedsatt kraft i proksimal ekstremitetsmuskulatur, som forsterket mistanken om inflammatorisk muskelsykdom. Man fant det lite sannsynlig at utvikling av en slik sykdom kunne settes i sammenheng med tidligere acitretinbehandling. Manifestasjoner som erytrodermi og begynnende nyresvikt kunne ikke forklares ut fra diagnosen dermatomyositt. Det relativt langtrukne forløpet talte imot rabdomyolyse.

Man mente at årsaken til den reduserte nyrefunksjonen mest sannsynlig var en kombinasjon av dehydrering og bruk av angiotensin II-antagonisten irbesartan. Dette hadde gitt hypotensjon og prerenal nyresvikt. Man valgte derfor å øke væsketilførselen og seponere irbesartan. Det ga raskt normalisering av nyrefunksjonen.

Som ledd i den videre utredningen av pasientens muskelidelse ble det tatt biopsi fra musculus vastus lateralis. Denne viste tverrstripet muskulatur med nevrogen atrofi, noen få spredte nekrotiske fibre og fokal økt oppregulering av MHC-1 (Major Histocompatibility Complex klasse 1). Det ble ikke sett perifascikulær atrofi eller inflammatoriske celler. Det histologiske bildet ga altså ingen sikre holdepunkter for dermatomyositt. Det var derfor behov for ytterligere utredning av pasienten.

De stafylokokkinfiserte hudlesjonene ble behandlet med dikloksacillin $500 \mathrm{mg}$ fire ganger daglig, og for å bedre allmenntilstanden ble det startet behandling med intravenøs metylprednisolon (Solu-Medrol) 1000 mg. Dagen etter var allmenntilstanden bedret og hudlesjonene noe avbleket. Verdiene for CK falt de neste tre dagene fra $9222 \mathrm{U} / \mathrm{l}$ til $2246 \mathrm{U} / \mathrm{l}$.

Pasienten ble så vurdert av øre-nesehals-lege, som ikke fant tegn til malign sykdom i munnhule, hals eller svelg. Undersøkelse av perifert blod viste uttalt lymfopeni, men ellers normal mikroskopi og immunofenotyping. Undersøkelse av beinmarg viste kun uttalt lymfopeni, og ved immunofenotyping ble det ikke funnet patologiske forhold. CT-undersøkelse av abdomen viste imidlertid en stor tumor i høyre leverlapp (diameter $143 \times 168 \times 150 \mathrm{mml}$ og en liten tumor $i$ venstre leverlapp (diameter $7 \times 14 \times 10 \mathrm{~mm}$ ) 


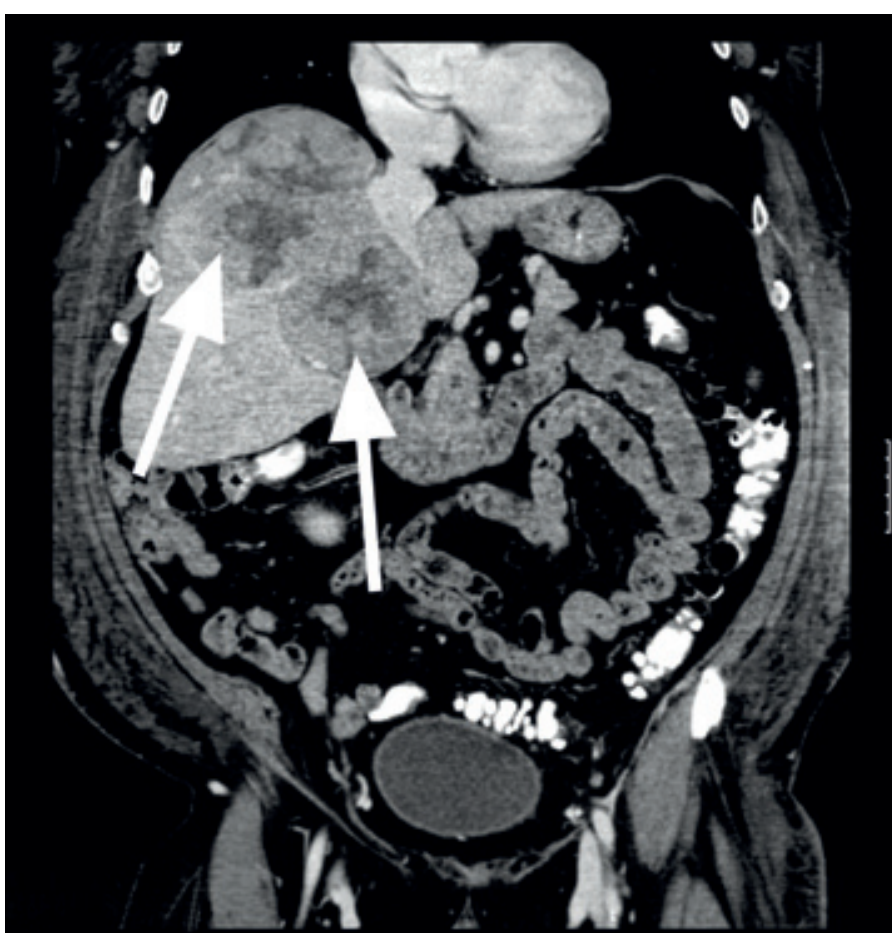

Figur 2 CT-undersøkelse av abdomen viste to tumorer i lever

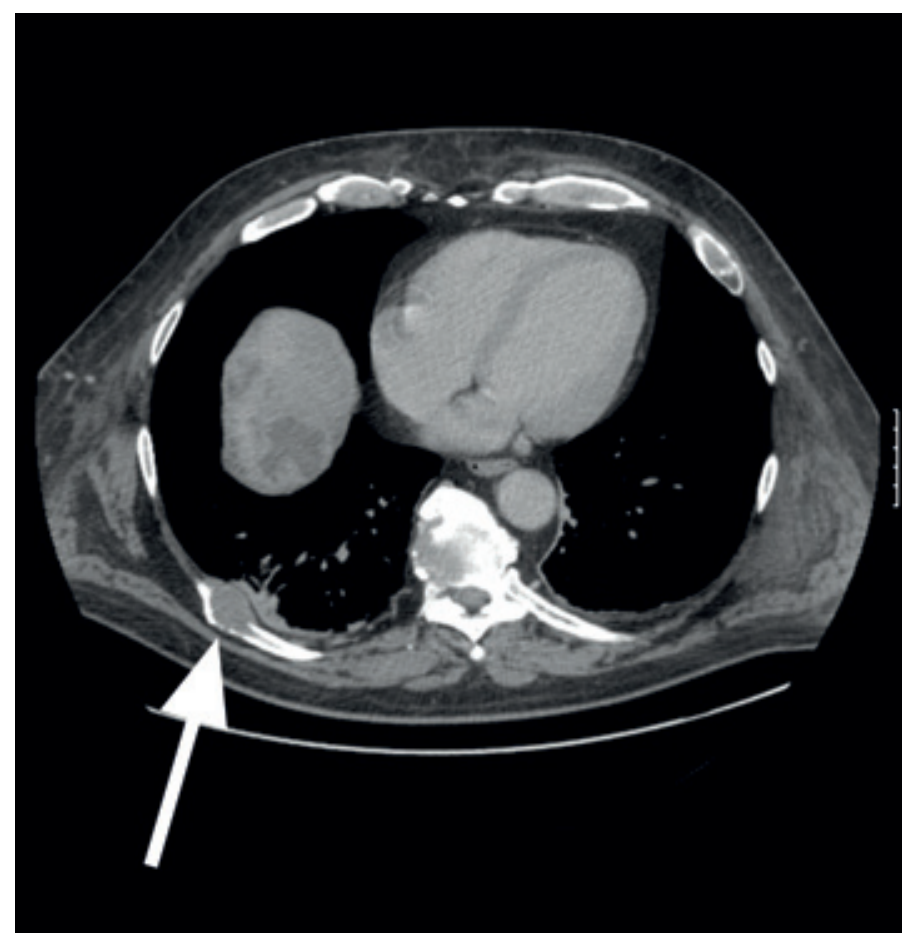

Figur 3 CT-undersøkelse av thorax viste metastase baktil i høyre niende ribbein (fig 2). CT-undersøkelse av thorax viste utstansede lesjoner i de tre første lumbalvirvlene forenlig med skjelettmetastaser. Baktil i høyre niende ribbein ble det påvist en destruerende tumoroppfylning som ekspanderte og infiltrerte åttende interkostalrom (fig 3). Alfaføtoprotein (AFP) var sterkt forhøyet $(1440 \mathrm{kU} / \mathrm{l}$ og steg senere til $1600 \mathrm{kU} /$ l)(normalt < 14).

Funnene av leversvulster sammen med metastaser til virvler og ribbein samt sterkt forhøyet alfa-1-føtoprotein var nærmest diagnostisk for hepatocellulært karsinom. Pasienten ble vurdert inoperabel både med hensyn til tumorreseksjon og levertransplantasjon.

\section{Diskusjon}

Pasienten hadde hatt psoriasis i flere år. Han responderte godt på acitretin, som imidlertid måtte seponeres på grunn av stigende nivå av leverenzymer. Leverenzymverdiene fortsatte imidlertid å stige etter seponeringen. Ved CT-undersøkelse av leveren ved lokalsykehus fant man to lesjoner i høyre leverlapp som ble tolket som hemangiomer. Med tid utviklet pasienten symptomer og funn som i sterk grad tydet på inflammatorisk muskelsykdom, og da spesielt dermatomyositt. Histologisk forelå det imidlertid ingen sikre tegn på en slik sykdom. Det ble derfor vurdert at det kliniske bildet av dermatomyositt kunne være ledd i en malign sykdom. Videre utredning viste at pasienten hadde hepatocellulært karsinom.

Dermatomyositt hos voksne er en velkjent paraneoplastisk tilstand (1). Oftest diagnostiseres kreftsykdom i tidsrommet fire år før til fire år etter start av muskelsykdommen (2). Hos pasienter med dermatomyositt ses malign sykdom 2-4 ganger hyppigere enn hva som forventes i denne aldersgruppen (1). De kreftformer som ses i sammenheng med dermatomyositt er de samme som utvikles i samme aldersklasse i befolkningen generelt, kanskje med overvekt av ovarialkreft (3). Alle pasienter med nyoppstått dermatomyositt etter 40-årsalderen bør derfor undersøkes med tanke på kreftsykdom.

Hepatocellulært karsinom er den vanligste primære formen for leverkreft og ses ofte i sammenheng med levercirrhose (3). Vår pasient hadde imidlertid ingen forhistorie med leversykdom. Pasienten hadde økte verdier av leverenzymer, sterkt forhøyet alfa-1-føtoprotein, lytiske forandringer $\mathrm{i}$ ribbein og ryggvirvler samt to typiske leversvulster påvist ved CT. Man mente derfor at leverbiopsi ikke var nødvendig for å bekrefte diagnosen.

Det skal imidlertid bemerkes at pasienten var tidligere undersøkt med CT og MR av lever, men funnet ble den gang oppfattet som hemangiomer. Dette viser at den radiologiske diagnostikken ved denne type svulster kan være vanskelig og at radiologiske funn bør sammenholdes med kliniske funn. At leverenzymverdien fortsatte å stige etter seponeringen av acitretin, burde nok ha ført til ytterligere utredning på et tidligere tidspunkt. En bedre kommunikasjon mellom radiolog og kliniker ville kunne ha avslørt at hemangiomer i lever ikke kunne forklare de kliniske og laboratoriemessige funnene.

$\mathrm{Vi}$ synes pasientens historie illustrerer dermatomyositt som en paraneoplastisk tilstand. Pasienter med systemiske bindevevs- sykdommer har ofte manifestasjoner fra både hud, bevegelsesapparatet og indre organer. Det er derfor svært viktig å ha et nært og godt samarbeid på tvers av medisinske spesialiteter i omsorgen for disse pasientene. Et tett samarbeid ville kunne sikre ensartede prosedyrer for utredning, diagnostikk og behandling av slike sjeldne tilstander. Man bør også vurdere om omsorgen for denne type sykdommer kan bedres ytterligere hvis den tas hånd om av avdelinger som innehar tilstrekkelig erfaring og kompetanse.

\section{Jan Tore Gran}

jan.tore.gran@rikshospitalet.no

Ragnar Gunnarsson

Revmatologisk avdeling

\section{Nils-Jørgen Mørk}

Hudavdelingen

Oslo universitetssykehus, Rikshospitalet 0027 Oslo

Pasienten har gitt samtykke til at artikkelen blir publisert.

Oppgitte interessekonflikter: Ingen

\section{Litteratur}

Yazici Y, Kagen LJ. The association of malignancy with myositis. Curr Opin Rheum 2000; 12 498-500.

2. Zantos D, Zhang Y, Felson D. The overall and temporal association of cancer with polymyositis and dermatomyositis. J Rheumatol 1994; 21: 1855-9.3. 3. Gomaa Al, Khan SA, Toledano MB et al. Hepatocellular carcinoma: epidemiology, risk factors and pathogenesis. World J Gastroenterol 2008; 14: 4300-8. 